\title{
A Study on Problem Solution of Culture Tourism Festival Through Big Data Analysis
}

\author{
Ji Su Hwang', Chang Liu², Guozhong Li ${ }^{3}$, Seong Taek Park ${ }^{* 4}$ \\ ${ }^{1}$ BA, Department of Business Administration, Sunmoon University, 31460 Korea \\ ${ }^{2}$ Professor, School of Economics and Management, Taishan University, 271000, China \\ ${ }^{2}$ Professor, Department of Management Science and Information System, Kunming University of Science and \\ Technology, 650500, China \\ ${ }^{4}$ Professor, Division of SW Convergence, Sunmoon University, 31460 Korea
}

\begin{abstract}
Background/Objectives: Accordingly, this study proposes the successful model of the culture tourism festival and suggest the direction to go in the future. For this, the author analyzed the culture tourism festival that is held in each region, and intends to determine focused on the festival, which showed low satisfaction, why the relevant culture tourism festival did so. Methods/Statistical analysis: In addition, the author checks the current status of the culture tourism festival and analyzes the participant's satisfaction by using the big data analysis tool, $\mathrm{R}$, and also uses the visualization function related to this. Findings: The model formula of the successful culture tourism festival was planned and analyzed by using R based on the report data issued by the Ministry of Culture, Sports, and Tourism. SNS data such as the problem of the regional festival that visitors who actually participated in the festival pointed out were collected (crawling) to suggest the measure for the culture tourism festival to be improved from the viewpoint of visitors. Improvements/Applications: This study tried to suggest the orientation of the culture tourism festival through analyzing the report issued by the Ministry of Culture, Sports, and Tourism and collecting the SNS data.
\end{abstract}

\section{Keyword}

Festival, big data, data analysis, solution, tourism festival

\footnotetext{
Corresponding author : Seong Taek Park

solpherd@gmail.com

- Manuscript received July 1, 2020.

- Revised July 27, 2020 ; Accepted August 5, 2020.

- Date of publication September 30, 2020.

(C) The Academic Society of Convergence Science Inc.

2546-1583 @ 2020 IJEMR. Personal use is permitted, but republication/redistribution requires IJEMR permission.
} 


\section{INTRODUCTION}

The Fourth Industrial Revolution, referred to as digital transformation, is receiving a lot of attention from around the world. Digital transformation consists mainly of artificial intelligence, big data, and networks, and studies on cloud, Internet of Things, and mobile have recently been conducted [1-4]. These digital technologies are also making a lot of difference to travel. Recently, Tripadvisor, Trip.dot Term, Sky Scanner, Agoda, Hotels.com are offering various services $[1,2]$.

Recently, various services have been provided due to the development of social media and smartphones. Companies are also using digital technology and social media for marketing [5-9].

The culture tourism festival started from the movement of each local government to activate its region through a festival or to develop the regional festival using the characteristics or culture of the city to convert the regional festival into the tourism product. The number of festivals continued to increase from 8 in 1996[10].

The culture tourism festival means the festival that the Ministry of Culture, Sports and Tourism selects and supports so that foreign tourists can be attracted and the activation of the regional economy can get help by using the local own specialties, cultural resources, and natural resources displayed at the regional festivals of Korea [11].

However, not the festival that owns the tradition and characteristics of each region but the festival that copied the festival of another region as it is is mass produced. The festival has been pointed out that it does not have the unique place characteristic of only the relevant region and is not a creative idea but is the uniform event-typed ceremony [12].

Accordingly, this study proposes the successful model of the culture tourism festival and suggest the direction to go in the future. For this, the author analyzed the culture tourism festival that is held in each region, and intends to determine focused on the festival, which showed low satisfaction, why the relevant culture tourism festival did so.

In addition, the author checks the current status of the culture tourism festival and analyzes the participant's satisfaction by using the big data analysis tool, $\mathrm{R}$, and also uses the visualization function related to this.

\section{RELATED WORK}

The Ministry of Culture, Sports, and Tourism, in 1966, started to select excellent regional festivals as culture tourism festivals and have nurtured and supported them. In the case of the early culture tourism festival, if a festival has the possibility of development, this festival was selected as the culture tourism festival.

However, a problem occurred that part of festivals that were selected as the culture tourism festivals failed to develop unlike the expectation and showed the limitation that they stayed at the level of regional festivals, thus the Ministry of Culture, Sports, and Tourism performed the ranking system in order to induce the culture tourism festivals to develop by themselves.

At the present, the ranking for festivals is divided into the representative festival, highest-level festival, excellent festival, and promising festival, and each festival is selected according to this ranking system.

\section{Study Method ANd Procedure}

This study collected the opinions on the critical views of participants of the culture tourism festivals through crawling, and tried to suggest the measure for resolving the problem about this.

In addition, this study went through the process that it planed the information data needed for success factors of the festival, and the usage analysis technique, and then implemented the analysis and visualization by using $\mathrm{R}$, an open source tool, and then took the procedure that interpreted the result of the above analysis and visualization [13-15].

\section{A. Correlation and descriptive statistics}

The current status of the culture tourism festival is that the festival is progressed with colorless programs and develops in the way of copying popular festivals. Furthermore, it was found that the festival developed not in the qualitative way but in the quantitative way.

In addition, since the unique features and culture of the region disappeared, the contents overlapping rate became higher [13].

Because of this, the participants' complaints of such festivals are getting more serious. In this regard, this study set the performance insufficiency compared to the budget and the low satisfaction of participants, as problems to try to suggest the 'desirable model of the culture tourism festival'.

\section{B. Correlation and descriptive statistics}

The current status of the culture tourism festival currently held and also the visitor's satisfaction are required. Thus, for determining the visitor's satisfaction, the relationship that affects the festival for each factor is analyzed through the questionnaire distributed by the Ministry of Culture, Sports, and Tourism in 2014 .

The success factors are deduced to suggest the desirable model of the successful festival and the failure factors are deduced to suggest the 
improvement measure [14].

\section{Correlation and descriptive statistics}

The related data are needed in order to induce the information necessary for understanding the problem $[13,15]$.

(1) The analysis on the performance of the culture tourism festival issued by the Ministry of Culture, Sports, and Tourism in 2014 in order to understand the current status of the culture tourism festival, and the study report on the measure for the selection and evaluation system improvement are the 1st analysis object data.

(2) The 2013 comprehensive evaluation report on the culture tourism festival.

(3) Comparison between the satisfaction and improvement of the culture tourism festivals of three years and what was actually improved, through the 2015 report on the selected details of the culture tourism festival.

(4) Understands the critical view on the culture tourism festival through the visitor's blog (naver).

\section{Correlation and descriptive statistics}

First of all, the information should be visualized so that the current statuses of the culture tourism festivals can be understood at one sight [16].

The culture tourism festival through which the consumption spending is the highest is represented by the gauge function, and the distribution and participation of the culture tourism festival of each region are executed through GGMAP $[17,18]$.

The satisfaction factors of the visitors for each festival are picked up to suggest the festival success expectation analysis formula through the multiple regression analysis. Moreover, the critical view on the culture tourism festival of visitors is implemented by the Word Clouds.

\section{DADA ANALYSIS}

As for the data needed for analysis, the portal of the Ministry of Culture and Tourism (www.mcst.go.kr) recently secured the selection details of the culture tourism festival of 2015, and the 2014 and 2013 comprehensive report of the culture tourism festival.

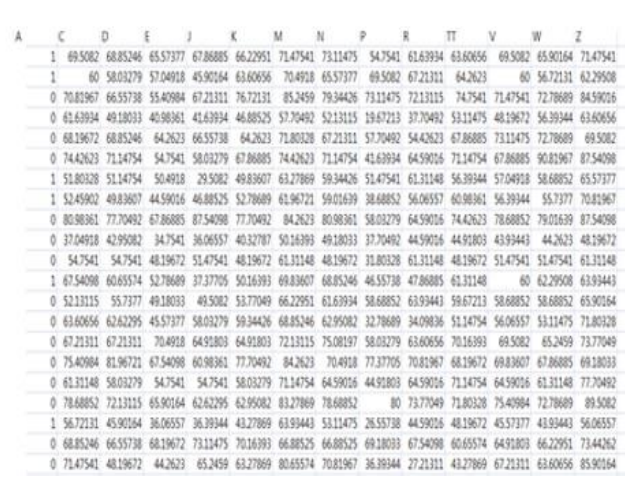

Fig. 1. Preprocessing of multiple regression analysis

The comprehensive report on the culture tourism festival includes the culture tourism festivals selected for each year, the satisfaction for each factor, of the visitors to each festival, and participation rate for each festival, and budget.

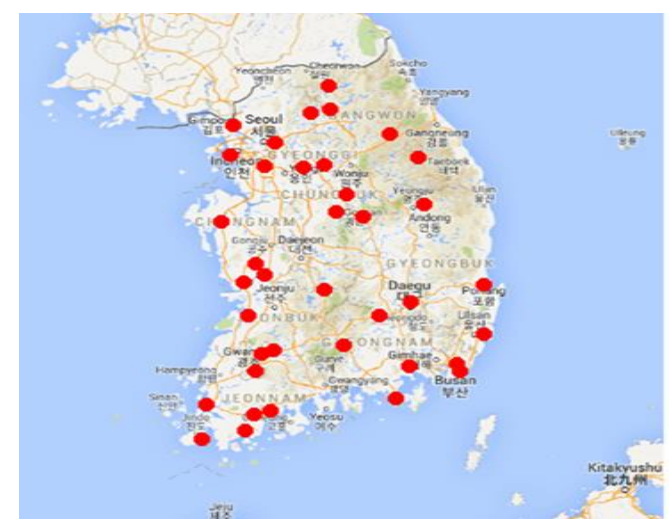

Fig. 1. Culture and Tourism Festival Status

The collected data were pre-processed to be converted into the form that can be analyzed, and the used data were converted to CSV to be used for analysis. The data were pre-processed so that they can meet the analysis situation.

In Jeollanam-do, a total of 6 festivals were selected as the culture tourism festivals, and here, the most culture tourism festivals are held. 


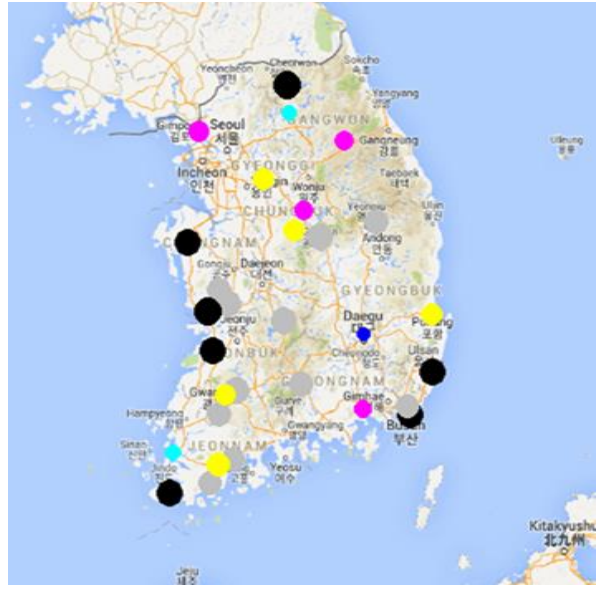

Fig. 1. Percentage of participants whose purpose is to visit the festival

The six festivals are held in Jeollanam-do, which is followed by five festivals in Gyeonggi-do, four festivals in Gangwon-do, and four festivals in Chungcheongnam-do in order.

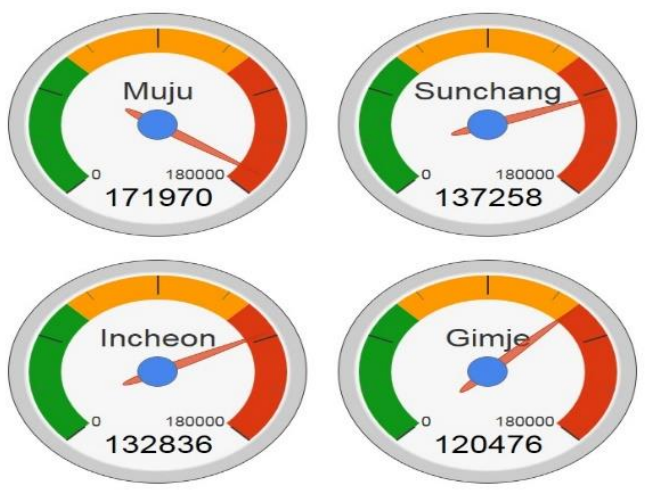

Fig. 1. Visitor consumption expenditure by festival

\section{THE EXPECTATION MODEL FOR SuCCESS FACTORS OF CULTURE TOURISM FESTIVAL}

With the satisfaction for each factor of the total of 25 factors of the comprehensive report on the 2014 culture tourism festival and the 2014 festival varied ranking compared to the 2013 one, the multiple regression analysis was performed.

As for the method to select a model, 25 variables were put in and the backward elimination that removes one by one from the variable that has the lowest contribution degree was used, which brought about the deduction of 13 variables.

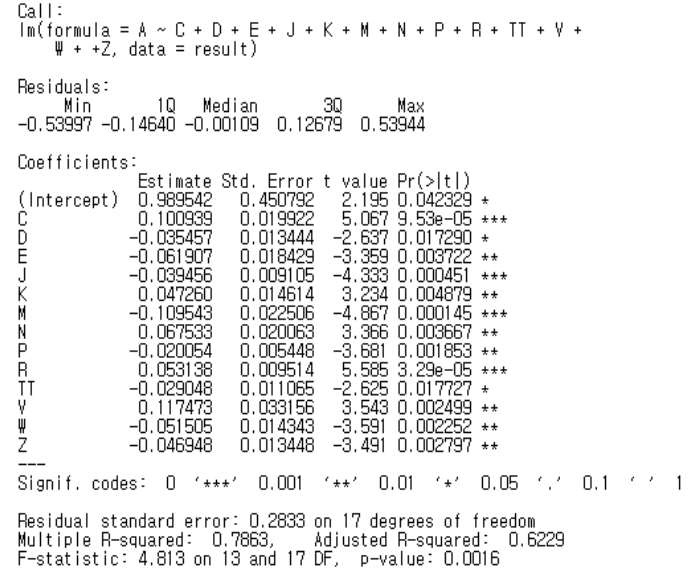

Fig. 1. Festival variable rank multiple regression analysis

\section{Criticism Factor of Culture TOURISM FESTIVAL}

To collect the criticism factor data of the culture tourism festival, the naver blog underwent crawling (was collected) to be represented by the text mining [19.20]. As a result, 20 factors were deduced.

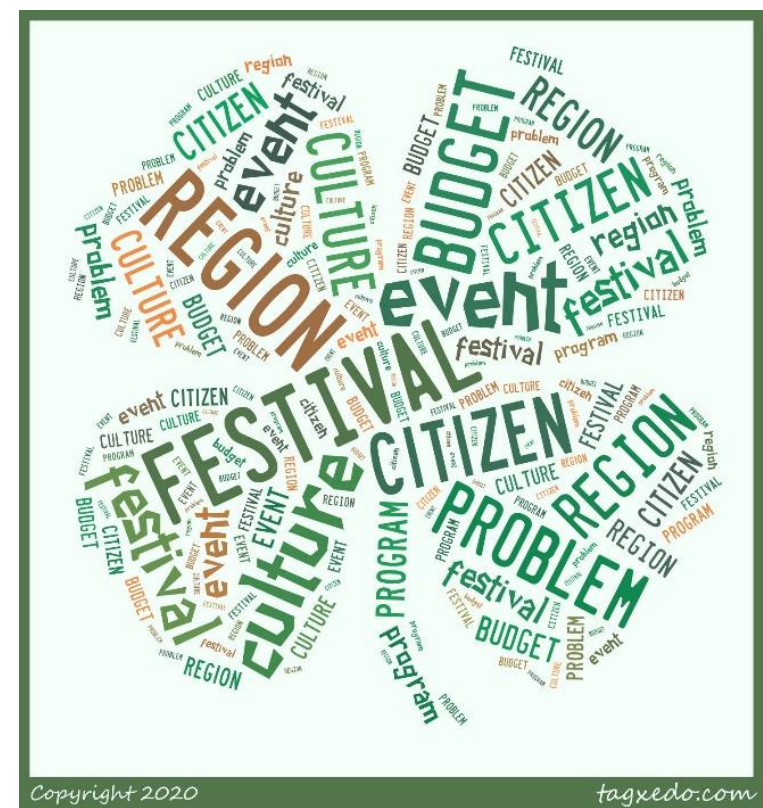

Fig. 1. Results of text mining, the condemning factor of the Cultural Tourism Festival

\section{Criticism Factor of Culture TOURISM FESTIVAL}

At the time when the culture tourism festival has lots of problems like today, the solution for this is urgent. In addition, many similar and overlapping festivals are created, and if the situation is continued in which these festivals fail to produce proper profits 
and only the precious money of the nation is invested, the culture tourism festival will not be welcomed by the nation.

In this regard, this study tried to suggest the orientation of the culture tourism festival through analyzing the report issued by the Ministry of Culture, Sports, and Tourism and collecting the SNS data.

The suggestive points of this study are as follows:

First, the model formula of the successful culture tourism festival was planned and analyzed by using $\mathrm{R}$ based on the report data issued by the Ministry of Culture, Sports, and Tourism.

Second, the SNS data such as the problem of the regional festival that visitors who actually participated in the festival pointed out were collected(crawling) to suggest the measure for the culture tourism festival to be improved from the viewpoint of visitors.

The limitation of this study is that this study did not analyze various data. The success factor of the festival was limited in only several variables issued by the Ministry of Culture, Sports, and Tourism.

As for the success factor of the festival, various other variables such as the event time, budget, visitor's sex and age, etc. should be considered in a complicated way.

The next study will have to secure various data based on the wider big data plan and analyze by the analysis technique that meets the various data, and prepare the appropriate measure.

\section{REFERENCES}

[1] Park, S. T., Li, G., \& Hong, J. C. (2020). A study on smart factory-based ambient intelligence contextaware intrusion detection system using machine learning. Journal of Ambient Intelligence and Humanized Computing, 11(4), 1405-1412.

[2] Park, S. T., \& Kim, Y. K. (2019). A Study on Deriving an Optimal Route for Foreign Tourists through the Analysis of Big Data. Journal of Convergence for Information Technology, 9(10), 56-63.

[3] Kim, Y. K., \& Park, S. T. (2018). Effects of Absorptive Capacity on Technology Innovation and Commercialization Capacities and Management Performance. Journal of the Korea Convergence Society, 9(12), 217-225.

[4] Lee, H. C., Park, S. T., \& Song, K. J. (2017). Analysis of Management Performance Change of Korean Agricultural Co-operatives around CEO turnover. Journal of Digital Convergence, 15(11), 175-185.

[5] Li, G., \& Park, S. (2017). A Study on Patent Valuation Factors. International Journal of Emerging Multidisciplinary Research, 1(2), 15-21.

[6] Jin, H., Wang, H., Park, S. T., \& Kim, Y. K. (2018). Research on Marketing Strategy of Traditional Retailers under the Background of Internet-A Case Study of Wal-Mart. INTERNATIONAL JOURNAL OF EMERGING MULTIDISCIPLINARY RESEARCH (IJEMR), 2(3), 27-32.
[7] Chang, L., Park, S. T., \& Yongfei, J. (2018). Using Casual Loop Diagramming to Explore the Drivers of Web Development. INTERNATIONAL JOURNAL OF EMERGING MULTIDISCIPLINARY RESEARCH (IJEMR), 2(3), 37-42.

[8] Li, G. (2019). An Introduction to the Mobile Payment Market and Trend in China. INTERNATIONAL JOURNAL OF EMERGING MULTIDISCIPLINARY RESEARCH (IJEMR), 3(1), 1-5.

[9] Jin, H., Duan, G., \& Park, S. T. A Study on Motivation to Consumer Social Information Search. INTERNATIONAL JOURNAL OF EMERGING MULTIDISCIPLINARY RESEARCH (IJEMR), 4(1), 7-10.

[10] Ministry of Culture, Sports and Tourism. (2015). A study on the achievements of the Cultural Tourism Festival and improvement plans for the selection and evaluation system

[11] Kang, Y. S., \& Cho, S. H. (2011). Strategies for Activating Local Cultural Festivals through Comparative Analysis of Outstanding Festivals. Resach of Dance Education, 11(2), 73-84.

[12] Ryu, J.A.(2013). Thesis of festival. Communication Books.

[13] Kim, K. W., Park, W. J., \& Park, S. T. (2015). A study on plan to improve illegal parking using big data. Indian Journal of Science and Technology, 8(21), 1.

[14] Park, E. M., Seo, J. H., \& Ko, M. H. (2016). The effects of leadership by types of soccer instruction on big data analysis. Cluster computing, 19(3), 1647-1658.

[15] Kim, D. Y., Park, S. T., \& Ko, M. H. (2018). A study on the analysis of IT-related occupational cluster using big data. IAENG International Journal of Computer Science, 45(1), 7-11.

[16] Kim, B. S., Kim, K. W., \& Park, S. T. (2015). The improvement plan for fire response time using Big data. Indian Journal of Science and Technology, 8(23), 1.

[17] Park, S. T., Kim, Y. R., Jeong, S. P., Hong, C. I., \& Kang, T. G. (2016). A case study on effective technique of distributed data storage for big data processing in the wireless internet environment. Wireless Personal Communications, 86(1), 239-253.

[18] Park, S. T., Lee, S. W., \& Kang, T. G. (2018). A study on the trend of cloud service and security through text mining technique. International Journal of Engineering \& Technology, 7(2.33), 127-132.

[19] Li, G., Dai, J. S., Park, E. M., \& Park, S. T. (2017). A study on the service and trend of Fintech security based on text-mining: Focused on the data of Korean online news. Journal of Computer Virology and Hacking Techniques, 13(4), 249-255.

[20] Park, E. M., \& Seo, J. H. (2019). A Study on Leadership Typology in Sports Leaders Based on Big Data Analysis. Journal of the Korea Convergence Society, 10(7), 191-198. 